\title{
Matylda Sierakowska, Irena Wrońska (red.), Edukacja zdrowotna w praktyce pielęgniarskiej, PZWL, Warszawa 2015, ss. 357
}

Książka dotyczy wybranych zagadnień z dydaktyki medycznej opracowanych pod kątem zawodowego kształcenia pielęgniarek. Ma przejrzystą dwudzielną strukturę. Pierwsza część obejmująca 124 strony dotyczy zagadnienia współczesnych wymiarów dydaktyki na rzecz zdrowia i w chorobie. Dużo obszerniejsza część druga jest poświęcona założeniom edukacji zdrowotnej w odniesieniu do praktyki pielęgniarskiej i współpracy interdyscyplinarnej (230 stron).

Tematyka książki odnosi się do edukacji zdrowotnej osób dorosłych. Dorośli mają już nawyki dotyczące zachowań zdrowotnych wykształcone na podstawie uwarunkowań genetycznych i współgrających z nimi czynników środowiskowych oraz psychospołecznych. Istnieją w tym zakresie znaczne różnice międzyosobnicze oraz występujące między grupami społecznymi. Poza profilaktyką, zagrożenie chorobą lub jej wystąpienie są czynnikami, które sprawiają, że konieczna staje się umiejętna edukacja zdrowotna. Jednym $z$ wielu zadań zawodowych pielęgniarki jest pełnienie roli edukatora zdrowia. Edukacja zdrowotna jest elementem szerszego pojęcia i zakresu działań - promocji zdrowia. Światowy autorytet w obszarze teorii edukacji zdrowotnej i promocji zdrowia D. Whitehead, omawiając rolę pielęgniarki jako pedagoga zdrowia, wyróżnia dwa atrybuty tej roli. Pierwsza kwestia to postulat modyfikacji zachowań przejawianych przez pacjenta, a szkodzących jego zdrowiu. Zmiana zachowań jest podejmowana wtedy, gdy znane są mierzalne zewnętrzne czynniki ryzyka zachorowania, na które można wpływać. Druga kwestia dotyczy założenia o otwartości jednostek na edukację prowadzącą do zmiany behawioralnej, gdyż ta edukacja może zmniejszyć ryzyko zachorowania lub poprawić stan zdrowia osób już chorujących (por. s. 33).

Część pierwsza książki koncentruje się na dwóch zagadnieniach. Ukazuje specyfikę kształcenia zawodowego w pielęgniarstwie w ogóle, a w za- 
kresie edukacji zdrowotnej w szczególności, oraz omawia metodykę edukacji zdrowotnej w kształceniu pielęgniarek. Irena Wrońska konstatuje, że na poziomie wyższym z zakresu edukacji zdrowotnej standard kształcenia zawodowego w pielęgniarstwie obejmuje 18 kompetencji, z których 8 należy do sfery kognitywnej, a 10 do sfery psychomotorycznej, według taksonomii Benjamina Blooma. Niestety tylko jedna kompetencja z zakresu sfery kognitywnej wymaga analitycznych umiejętności intelektualnych (czwarty poziom, z sześciu w taksonomii Blooma), a pozostałe siedem należy do drugiego poziomu, to znaczy rozumienia wiedzy. Oznacza to, że w celach kształcenia pielęgniarek nacisk położony jest na odtwórcze przyswajanie wiedzy, a wyższe kategorie sfery kognitywnej, jak ocenianie i tworzenie (w tym przypadku: programów edukacji zdrowotnej), nie pojawiają się. Z kolei z dominującej w standardzie kształcenia sfery kompetencji psychomotorycznych wszystkie dziesięć kompetencji należy „co najmniej do czwartego poziomu złożoności ich wykonywania i reagowania na zaistniałe okoliczności" (s. 26). Zatem jakość kształcenia w tej sferze jest wyraźnie wyższa od jakości w zakresie sfery kognitywnej.

W drugiej części pracy znajdujemy na początku krótkie omówienie założeń teoretycznych tworzenia interdyscyplinarnych programów w obszarze promocji zdrowia oraz zwięzłą charakterystykę rodzimych populacyjnych programów zdrowotnych finansowanych przez Ministerstwo Zdrowia, Narodowy Fundusz Zdrowia oraz samorząd terytorialny (odpowiedzialny za stan zdrowia społeczności lokalnych). Większość tej części książki zajmują konkretne opracowania projektów programów edukacyjnych dla pacjentów i/lub ich opiekunów w następujących chorobach przewlekłych: reumatycznych, dermatologicznych, układu pokarmowego, układu sercowo-naczyniowego, układu oddechowego, neurodegeneracyjnych, w chorobach nerek oraz w wybranych problemach geriatrycznych.

Uważam, że warto sięgnąć do tej książki, aby zdać sobie sprawę z dydaktycznego standardu w dwóch wymiarach: nauczania zawodowego w zakresie edukacji zdrowotnej w pielęgniarstwie oraz tworzenia przez pielęgniarki programów zdrowotnych. Ta praca jest jednocześnie ważnym źródłem wiedzy dla pedagogów specjalnych i studentów tego kierunku oraz wszystkich pedagogów specjalizujących się w opiece nad wybranymi grupami społecznymi.

Hanna Kostyło 